University of Nebraska - Lincoln

DigitalCommons@University of Nebraska - Lincoln

Agronomy \& Horticulture -- Faculty Publications

Agronomy and Horticulture Department

1957

\title{
Influence of Various Factors on Aggregation of Peorian Loess by Microorganisms
}

\author{
T. M. McCalla \\ United States Department of Agriculture \\ Francis A. Haskins \\ University of Nebraska-Lincoln, fhaskins@neb.rr.com \\ E. F. Frolik \\ United States Department of Agriculture
}

Follow this and additional works at: https://digitalcommons.unl.edu/agronomyfacpub

Part of the Plant Sciences Commons, and the Soil Science Commons

McCalla, T. M.; Haskins, Francis A.; and Frolik, E. F., "Influence of Various Factors on Aggregation of Peorian Loess by Microorganisms" (1957). Agronomy \& Horticulture -- Faculty Publications. 206. https://digitalcommons.unl.edu/agronomyfacpub/206

This Article is brought to you for free and open access by the Agronomy and Horticulture Department at DigitalCommons@University of Nebraska - Lincoln. It has been accepted for inclusion in Agronomy \& Horticulture -Faculty Publications by an authorized administrator of DigitalCommons@University of Nebraska - Lincoln. 


\title{
INFLUENCE OF VARIOUS FACTORS ON AGGREGATION OF PEORIAN LOESS BY MICROORGANISMS
}

\author{
T. M. McCALLA, F. A. HASKINS, and E. F. FROLIK \\ United States Department of Agriculture ${ }^{1}$ \\ Received for publication January 2, 1957
}

Soil structure is important in the attainment of adequate aeration for the aerobic microorganisms whose activities maintain such higher plant nutrients as sulfur, phosphorus, and nitrogen in a highly oxidized and thus readily available state. Good soil structure is also necessary for soil and water conservation. Under Nebraska conditions microorganisms and their decomposition products constitute a major source of soil-aggregating agents. The decomposition of crop residues and plant roots is important in the nutrition of these aggregating microorganisms. Other microorganisms, however, also utilize crop residues and plant roots, and they may decompose the aggregating agents as well, so that the aggregation produced may be only temporary. Thus the net effect of the entire soil microflora on soil structure is difficult if not impossible to predict. As a first step in gaining some understanding of the influence of the microflora on soil structure and ultimately in attempting some control of structure, it was deemed necessary to extend previous work $(3,4,5)$ dealing with the effects of pure cultures on structure.

This paper presents the results of studies in which a number of different microorganisms, which were isolated at random from Nebraska soils, have been compared with respect to their ability to aggregate Peorian loess. In addition, for the better aggregators it presents the results of studies which sought to determine the conditions of time, temperature, moisture level, and the nature and concentration of energy source necessary for maximum aggregation. The results of a similar study dealing with a group of cellulose-decomposing fungi have been reported elsewhere (2).

MATERTALS AND METHODS

\section{Cultures}

For the determination of aggregation produced by a variety of naturally oceurring soil fungi, soil samples were taken at various locations in Nebraska ${ }^{2}$. For the isolation of fungi, rose bengal was added to the medium to give a final concentration of 1:15,000 to control bacterial growth. Cultures of 33 fungi and one

\footnotetext{
${ }^{1}$ Contribution by the Soil and Water Conservation Research Branch, Agricultural Research Service, U. S. Department of Agriculture, and the Department of Agronomy, Nebraska Agricultural Experiment Station, Lincoln, cooperating. Published with the approval of the Director as Paper No.668, Journal Series, Nebraska Agricultural Experiment Station.

${ }^{2}$ Obtained from W. W. Ray (Botany Department) and M. G. Boosalis (Plant Pathology Department). The writers are indebted to Dr. Ray for his identification of a large number of fungi used.
} 
actinomycete were obtained in this manner. In addition, a number of other fungi were used. All cultures were maintained on nitrate-sucrose agar (1).

\section{Soil material}

Peorian loess obtained a few feet below surface from a road cut near Plattsmouth, Nebraska, was used as a substrate because it is low in organic matter and essentially devoid of decomposition products of microorganisms/The moisture contents of this material at $1 / 3$ and 15 atmospheres tension were 21.3 and 8.0 per cent, respectively. The structural characteristics of this soil material are altered by autoclaving much less than those of a soil high in organic matter. All Peorian loess used in these experiments was screened through a 2 -mm. sieve.

\section{Aggregation assays}

In assaying the aggregating ability of the cultures, triplicate Petri plates were used for each treatment. Each plate contained $35 \mathrm{~g}$. of Peorian loess. All plates of Peorian loess were autoclaved for 1 hour at a steam pressure of approximately $15 \mathrm{lb} . / \mathrm{sq}$. in. Wheat straw, for those treatments where it was used, was ground in a Wiley mill to pass the $2-\mathrm{mm}$. screen and then mixed with the Peorian loess and sterilized. Where sugar was used as the carbon source, a sterile solution of sucrose was added with the inoculum. All inocula were prepared in a sterile salt solution of the following composition: $\mathrm{NH}_{4} \mathrm{NO}_{3}, 8 \mathrm{~g} . ; \mathrm{K}_{2} \mathrm{HPO}_{4}, 4 \mathrm{~g}$. $\mathrm{MgSO}_{4} \cdot 7 \mathrm{H}_{2} \mathrm{O}, 2 \mathrm{~g}$.; $\mathrm{FeSO}_{4}$, less than $0.1 \mathrm{~g}$; and $\mathrm{H}_{2} \mathrm{O}, 1000 \mathrm{ml}$.

Inocula were diluted in such a way that during inoculation each plate received the equivalent of $3.5 \mathrm{ml}$. of this salt solution and, at the same time, sufficient water to produce the desired moisture level.

Following incubation of the plates, the degree of aggregation was determined by a wet-sieving method previously described (2). A 10-g. sample of the Peorian loess was weighed into the cylinder, presoaked in water for 5 minutes, and then oscillated for 5 minutes at the rate of 282 -inch cycles per minute. The aggregated material was then washed from the top of the $0.2-\mathrm{mm}$. screen into an evaporating dish and dried and weighed. Duplicate samples were taken from each Petri plate, making a total of six determinations for each treatment. An additional $10 \mathrm{~g}$. sample was taken from each Petri plate for moisture determination. The per cent argregation was calculated from the dry weights of the aggregates and moisture samples.

\section{PESULTS}

Aggregating ability of various cultures

The results of experiments in which 33 fungi and one actinomycete isolated at random were cultured on Peorian loess with straw or sucrose ( 1 per cent concentration) as the carbon sources are shown in table 1 . At the start of the experiments the addition of inocula brought the moisture content of the soil in all plates to 25 per cent. An incubation temperature of $24^{\circ} \mathrm{C}$. and an incubation time of 2 weeks were used.

The fact that the degree of aggregation attained is generally much higher with sucrose than with straw as an energy source indicates that, as might be expected, sucrose is the more readily available source of energy. There are wide difference among cultures with respect to the degree of aggregation attained; in the case of straw only a few cultures bring about aggregation percentages exceeding 30 per cent. Thus the nature of the microorganisms which decompose crop residues appears to be of extreme importance in determining effects on soil aggregation.

The genera of these cultures, isolated at random, were identified and the aggregating abilities of 19 other cultures of fungi and actinomycetes of known genera were assayed as already described. The results, classified according to the genera of the cultures, are presented in table 2 . Apparently there are considerable differences in aggregating ability between genera and also within any particular genus. The results emphasize again the superiority of sugar over straw as a carbon source. The highest degrees of aggregation with sugar as the carbon source were attained with species of Aspergillus and Alternaria, whereas with straw, species of Fusarium and Alternaria were outstanding.

\section{Effects of varying cullural conditions on degree of aggregation}

Two of the most promising fungi, a Fusarium of the Elegans group and a Fusarium of the Discolor group, and one of the Streptomyces tested in the preceding experiments were investigated further to determine the cultural conditions best suited for aggregation. Carbon source concentration, moisture con tent, incubation time, and temperature were varied in these experiments.

Nature and concentration of carbon source. Two of the cultures, Streptomyces and Fusarizm of the Discolor group, were tested at five levels, $0.25,0.5,1.0$, 1.5 , and 2.0 per cent of sucrose and on a 1 per cent concentration of straw. The Fusarium of the Elegans group was tested on straw at the five concentrations and on 1 per cent sucrose. All treatments were adjusted to 25 per cent moisture and

TABLE 1

Variation in aggregation of Peorian loess brought about by 34 soil isolates with straw and ucrose as energy materials

\begin{tabular}{c|c|c}
\hline $\begin{array}{c}\text { Energy Material } \\
\text { 1\% Concentration) }\end{array}$ & Aggregation Range* & Number of Cultures \\
\hline & $\%$ & \\
Straw & 10 or less & 19 \\
& $11-20$ & 8 \\
$21-30$ & 4 \\
& $31-40$ & 1 \\
& $41-50$ & 2 \\
\hline \multirow{3}{*}{ Sucrose } & 30 or less & 2 \\
& $31-45$ & 7 \\
& $46-60$ & 18 \\
& $61-75$ & 4 \\
\hline
\end{tabular}

"Uninoculated control $=$ 
TABLE 2

Aggregation of Peorian loess by various genera of fungi and actinomycetes with sucrose and straw as the energy source

\begin{tabular}{|c|c|c|c|c|c|}
\hline \multirow{3}{*}{ Genus } & \multirow{3}{*}{$\begin{array}{c}\text { Number of } \\
\text { Cultures }\end{array}$} & \multicolumn{4}{|c|}{ Aggregation } \\
\hline & & \multicolumn{2}{|c|}{ Sucrose* } & \multicolumn{2}{|c|}{ Straw* } \\
\hline & & Range & Mean & Range & Mean \\
\hline & & $\%$ & $\%$ & $\% 1$ & $\%$ \\
\hline Aspergillus. & 23 & $40.0-83.8$ & 64.2 & $2.2-32.6$ & 11.4 \\
\hline Fusarium. & 7 & $40.0-74.7$ & 68.8 & $3.7-46.6$ & 12.4 \\
\hline Streptomyces. & 4 & $29.4-57.4$ & 41.5 & $3.9-4.5$ & 4.1 \\
\hline Penicillium. & 3 & $25.7-70.4$ & 52.0 & $3.6-4.5$ & 4.1 \\
\hline Chaetomium. & 3 & $30.5-40.5$ & 36.5 & $10.5-15.1$ & 13.5 \\
\hline Myrothecium. & 3 & $23.9-58.6$ & 45.8 & $2.5-14.0$ & 10.3 \\
\hline Alternaria.. & 2 & $67.0-84.1$ & 75.6 & $33.4-46.0$ & 39.7 \\
\hline Rhizoctonia. & 2 & $42.4-46.5$ & 44.5 & $5.0-11.4$ & 8.2 \\
\hline Cladosporium. & 2 & $20.0-20.4$ & 20.2 & $3.0-3.1$ & 3.1 \\
\hline Mucor. & 2 & $65.9-66.8$ & 66.4 & $10.6-15.9$ & 13.3 \\
\hline Trichoderma. & 2 & $56.2-61.9$ & 59.1 & $3.4-3.5$ & 3.5 \\
\hline None......... & & & 4.0 & & 4.0 \\
\hline
\end{tabular}

* In 1 per cent concentrations.

TABLE 3

Influence of different concentrations of energy materials on the aggregation effected by three cultures

\begin{tabular}{c|c|c|c}
\hline \multirow{2}{*}{ Concentration of Energy Material } & \multicolumn{3}{|c}{ Aggregation } \\
\cline { 2 - 4 } & \multicolumn{2}{|c|}{ Sucrose } & Straw \\
\cline { 2 - 4 } & $\begin{array}{c}\text { Fissarium sp. } \\
\text { Sireptomyces sp } \\
\text { (Discolor group) }\end{array}$ & $\begin{array}{c}\text { Fusarium } \mathrm{sp} . \\
\text { (Eliscolor groun })\end{array}$ \\
\hline$\%$ & $\%$ & $\%$ & $\%$ \\
0.25 & 16.2 & 48.1 & 7.0 \\
0.50 & 17.5 & 57.3 & 23.7 \\
1.00 & 25.5 & 68.4 & 34.6 \\
1.50 & 27.7 & 87.6 & 41.6 \\
2.00 & 29.0 & 89.1 & 46.8 \\
\hline L.S.D. & & & \\
energy material............... & 4.8 & 18.7 & 7.3 \\
\hline
\end{tabular}

Note. Fusarium (Elegans group) gave $78.8 \%$ aggregation with $1.0 \%$ sucrose; Streptomyces $4.7 \%$ with $1.0 \%$ sucrose; and Fusarium (Discolor group) $5.3 \%$ with $1.0 \%$ straw.

were incubated at $24^{\circ}$ for 2 weeks. Results of aggregate analyses are shown in table 3.

It is apparent that both concentration and nature of carbon source have an important influence on aggregation and that higher concentrations of carbon source generally result in increased aggregation. For purposes of comparison, however, a concentration of 1 per cent seemed suitable.
TABLE 4

Influence of different levels of moisture on the aggregation effected by three cultures

\begin{tabular}{c|c|c|c|c}
\hline \multirow{2}{*}{ Moisture Content } & \multicolumn{3}{|c}{ Aggregation } \\
\cline { 2 - 3 } & No organism & $\begin{array}{c}\text { Streptomyces sp. } \\
\text { (Discolor rroup) }\end{array}$ & $\begin{array}{c}\text { Fusarium sp. } \\
\text { (Elegans group) }\end{array}$ & $\begin{array}{c}\text { Fusarium sp. } \\
\text { (Discolor group) }\end{array}$ \\
\hline$\%$ & $\%$ & $\%$ & $\%$ & $\%$ \\
10 & 1.2 & 2.1 & 5.8 & 60.2 \\
15 & 1.5 & 13.6 & 16.8 & 82.7 \\
20 & 1.3 & 25.8 & 30.7 & 90.2 \\
25 & 1.4 & 29.3 & 44.6 & 86.6 \\
30 & 1.3 & 31.6 & 44.1 & 86.0 \\
\hline L.S.D. (5\%) between & & & & \\
moisture levels................... & 5.7 & 14.5 & 10.2 \\
\hline
\end{tabular}

Moisture content. Five moisture contents, 10,15, 20, 25, and 30 per cent, were tested with the three cultures. Wheat straw at a concentration of 1 per cent was used for the Elegans group of Fusarium and 1 per cent sucrose was used for the other two cultures. Aggregations were determined after incubating for 2 weeks at $24^{\circ} \mathrm{C}$. The results are presented in table 4

The 10 per cent moisture content, which is slightly greater than the moisture content at 15 atmospheres tension ( 8.0 per cent) was definitely suboptimal for all three cultures tested, and in all cases an increase of moisture from 10 to 20 per cent resulted in a substantial increase in aggregation. In general, an increase of moisture content above the 25 per cent level, which is slightly higher than the moisture content at $1 / 3$ atmospheres tension (21.3 per cent), did not appreciably influence the degree of aggregation.

Temperature. In an experiment designed to study the effect of temperature on aggregation, plates of Peorian loess were inoculated with the three cultures and incubated for 2 weeks at $20^{\circ}, 24^{\circ}$, and $28^{\circ} \mathrm{C}$. Wheat straw was supplied to the plates of Fusarium of the Elegans group at a concentration of 1 per cent and the other two cultures were supplied with a like concentration of sucrose. An initial moisture content of 25 per cent was used in all plates. Aggregate analysis results (table 5)

TABLE 5

Influence of different temperatures on the aggregation effected by three cultures

\begin{tabular}{c|c|c|c|c}
\hline \multirow{2}{*}{ Temperature } & \multicolumn{4}{|c}{ Aggregation* $^{*}$} \\
\cline { 2 - 5 } & No organism & $\begin{array}{c}\text { Sireptomyces sp. } \\
\text { (Discolor group) }\end{array}$ & $\begin{array}{c}\text { Fusarium sp. } \\
\text { (Elegans group) }\end{array}$ & $\begin{array}{c}\text { Fissarium sp. } \\
\text { (Discolor group) }\end{array}$ \\
\hline degrees C. & $\%$ & $\%$ & $\%$ & $\%$ \\
20 & 1.4 & 26.6 & 34.9 & 88.3 \\
24 & 1.6 & 27.4 & 29.9 & 88.1 \\
28 & 1.7 & 28.9 & 40.1 & 86.1 \\
\hline
\end{tabular}

* Aggregation differences between temperatures were not significant at the $5 \%$ level for any of the cultures. 
TABLE 6

Influence of incubation interval on the aggregation effected by three cultures

\begin{tabular}{c|c|c|c|c}
\hline \multirow{2}{*}{ Incubation Interval } & \multicolumn{4}{|c}{ Aggregation } \\
\cline { 2 - 5 } & No organism & $\begin{array}{c}\text { Streplonyces sp } \\
\text { (Discolor group) }\end{array}$ & $\begin{array}{c}\text { Fusarium sp. } \\
\text { (Elegans group) }\end{array}$ & $\begin{array}{c}\text { Fusarium sp. } \\
\text { (Discolor group) }\end{array}$ \\
\hline$w k$. & $\%$ & $\%$ & $\%$ & $\%$ \\
0.5 & 2.7 & 25.2 & 12.7 & 73.2 \\
1 & 1.5 & 33.0 & 43.6 & 83.0 \\
2 & 1.8 & 34.9 & 27.9 & 83.3 \\
4 & 1.5 & 40.1 & 28.4 & 83.0 \\
8 & 1.9 & 48.6 & 45.4 & 90.0 \\
12 & 46.1 & - & 91.4 \\
\hline L.S.D. (5\%) between time intervals... & 7.5 & 6.0 & 9.6 \\
\hline
\end{tabular}

indicate that under the conditions of the experiment a variance of temperature between $20^{\circ}$ and $28^{\circ} \mathrm{C}$. has little effect on aggregation.

Incubation time. The effect of incubation interval on aggregation was studied for the three cultures, using the same levels of moisture and carbon source as were used in the temperature experiment and incubating the plates for $0.5,1,2$, 4,8 , and 12 weeks at $24^{\circ} \mathrm{C}$. The results are presented in table 6. Aggregation proceeded rapidly during the first week of incubation, but increasing the incubation period from that point to as long as 12 weeks had little effect on aggregation.

DISCUSSION

From these studies different fungi apparently vary widely in their effects on soil agrregation. Similar results have been obtained with bacteria and actinomycetes (4). Since most of the cultures tested were isolated from the soil, it follows that many of the organisms which make up the soil microflora grow at the expense of crop residues such as straw without contributing very much to soil aggregation $(3,5)$. It is safe to say that if the maximum benefit with respect to soil aggregation is to be realized from crop residue, attention will need to be given to the selection and use of the effective microorganisms and to providing an enviromment which is most favorable for these microorganisms.

\section{SUMMARY}

Thirty-three fungi and one actinomycete were isolated from Nebraska soils and tested for their effectiveness in aggregating Peorian loess. In addition, a number of other fungi and actinomycetes were tested for aggregating ability with straw and sucrose as energy sources. Three of the more effective cultures were selected and tested for agrregating ability under various levels of carbon source, moisture, temperature, and time. Large differences in aggregating ability were found among the different cultures.

In general, the aggregation effected with sucrose as a source of energy was con- siderably higher than that obtained with straw, and only a few cultures were found to promote appreciable aggregation with straw as the carbon source. Under favorable conditions of temperature, moisture, and energy source in the laboratory, the more effective cultures promoted a high degree of aggregation of Peorian loess in a relatively short time ( 3 to 7 days)

\section{REFERENCES}

(1) ALLEN, O. N. 1949 Experiments in Soil Bacteriology. Burgess Publishing Company Minneapolis, Minnesota.

(2) Downs, S. C., McCalia, T. M., and Haskins, F. A. 1955 Stachybotrys atra, An effective aggregator of Peorian loess. Soil Sci. Soc. Amer. Proc. 19: 179-181.

(3) Gilmour, C. M., Alden, O. N., And Truon, E. 1948 Soil aggregation as influenced by the growth of mold species, kind of soil, and organic matter. Soil Sci. Soc. Amer. Proc. 13: 292-296.

(4) MoCALta, T. M. 1946 Influenee of some microbial groups on stabilizing soil strue ture against falling water drops. Soil Sci. Soc. Amer. Proc. 11: 260-263.

(5) SWABY, R. J. 1949 The relationship between microorganisms and soil agregation J. Microbiol. 3: 236-254. 